\title{
NITRATE AND PHOSPHATE CONTENTS IN CATFISH SEED REARING PONDS WITH VARIOUS FREQUENCIES OF WATER HYACINTH REPLACEMENT (EICHHORNIA CRASSIPES)
}

\author{
Lumbessy Salnida Yuniarti ${ }^{\star}$, Diniarti Nanda, Famila B.J. Ega Puspita \\ Study Program of Aquaculture, Faculty of Agriculture, University of Mataram, Indonesia \\ *E-mail: alyachali@gmail.com
}

\begin{abstract}
Nitrate $\left(\mathrm{NO}_{3}\right)$ and phosphate $\left(\mathrm{PO}_{4}\right)$ are the main inorganic nutrients required for water hyacinth or eceng gondok ( $E$. crassipes) to grow. Administration of water hyacinth in fish farming activities can intensively improve water quality because water hyacinth utilizes nitrates and phosphates in aquaculture media resulting from fish body metabolism excretion. This research aimed to study intensively the distribution of nitrate and phosphate with various frequencies of water hyacinth change. This research used a completely randomized design (CRD) with four treatments of water hyacinth change frequency, repeated four times. The given treatments included: A) Without the administration of water hyacinth (control), B) administration of water hyacinth without replacement, C) water hyacinth replacement every 3 weeks, and D) water hyacinth replacement every two weeks. Parameters observed were nitrate and phosphate levels. Specific Growth Rate (SGR) of water hyacinth and Daily Growth Rate (DGR) of catfish seeds once a week for 42 days of rearing. The results of this research indicate that the frequency of water hyacinth replacement every two weeks (B) can reduce nitrate content to $0.79 \mathrm{mg} / \mathrm{L}$ and phosphate content to $0.06 \mathrm{mg} / \mathrm{L}$ at the end of the rearing period, so the average Daily Growth Rate (DGR) of catfish seeds increased by $5.46 \% /$ day. The frequency of water hyacinth replacement every two weeks and every three weeks has the same effect on increasing the Specific Growth Rate (LPS) of water hyacinth.
\end{abstract}

\section{KEY WORDS}

Nitrate, phosphate, Catfish (Claria sp.), frequency, water hyacinth (E. crassipes).

Catfish (Clarias sp.) is a freshwater commodity that is widely cultivated intensively with high stocking densities. The high increase in stocking density is always followed by an increase in the amount of feed, causing farming waste problems. Aquaculture wastes such as leftover food and feces discharged into the waters are potential organic contaminants in the form of nitrogen $(\mathrm{N})$ and phosphorus $(\mathrm{P})$ which can affect the levels of fertility and water quality feasibility for cultivated fish life, especially oxygen. If organic material is not managed properly, it will pollute the aquaculture media environment. This can cause a decline in water quality to affect the growth of fish, even lead to death.

One solution to overcome the decline in the water quality of aquaculture media is to apply a phytoremediation technology system through the utilization of aquatic plants. Water hyacinth or eceng gondok (E. crassipes) is a type of aquatic plant that can be used as a phytoremediator for waste in waters (Adeniran, 2011; Vesely et al., 2011; Ochekwu and Madagwa, 2013; Ugya and Imam, 2015).

Waste commonly generated from intensive aquaculture activities in the form of inorganic nitrogen (ammonia, nitrate, nitrite, and phosphate) which can harm fish cannot be utilized directly by aquatic plants. Instead, it must first go through the process of fixation to ammonia $\left(\mathrm{NH}_{3}\right)$, ammonium $\left(\mathrm{NH}_{4}{ }^{+}\right)$, and nitrate $\left(\mathrm{NO}_{3}\right)$. Nitrogen has a direct negative impact on fish growth and immunity. The breakdown of organic nitrogen (protein, urea, feces) and inorganic nitrogen originating from the decomposition of organic matter by microbes or fungi will produce ammonia $\left(\mathrm{NH}_{3}\right)$. Ammonia is a metabolic waste, which is, at a certain concentration, very toxic to aquatic organisms (Benli et al., 2008; Remen et al., 2008; Boyd, 2015). Skriptsova and Miroshnikova (2013) stated that nitrogen can be used by aquatic 
plants to produce protein and chlorophyll whereas phosphate has an important role in energy transportation and also the formation of DNA, RNA, and phospholipids.

Utilization of water hyacinth as a phytoremediator in fish farming has been widely applied, but there is still little information on how the utilization of water hyacinth by using the replacement technique during fish farming affects water quality. Thus, this research was conducted to examine the distribution of nitrate and phosphorus in intensive catfish farming with various frequencies of water hyacinth replacement.

\section{MATERIALS AND METHODS OF RESEARCH}

This research used catfish seeds as the tested animal and water hyacinth as the aquatic plant biota. This research used a completely randomized design (CRD) with four treatments of water hyacinth replacement frequency, each of which was repeated four times. The treatments were A). Without the administration of water hyacinth (control), B). Administration of water hyacinth without replacement, C) Replacement of water hyacinth every three weeks, and D). Replacement of water hyacinth every two weeks.

Catfish seeds used were first adapted in a rearing container for 10-15 minutes. The catfish seeds used had an initial weight of $\pm 5 \mathrm{~g}$. As much as 200 seeds were spread per $\mathrm{m}^{2}$ in each $50 \times 50 \mathrm{~cm}$-sized rearing pool. The rearing was conducted for 42 days with a commercial feeding frequency of 3 times per day. Water hyacinth used in this research amounted to $\pm 1000 \mathrm{~g}$ wet weight for each rearing pool.

Observations and measurements were made of nitrate and phosphate levels, the Specific Growth Rate of water hyacinth plant and the Daily Growth Rate of catfish seeds once a week for 42 days of rearing. Nitrate and phosphate are measured using spectrophotometric methods. The Specific Growth Rate of water hyacinth for a certain time was calculated using the following formula (Brown, 1997):

$$
\% W_{t}=\frac{W_{t}-W_{o}}{W_{t} \times t} \times 100 \%
$$

Where: \% Wt/day - Specific Growth Rate (\%); W0 - Initial Wet Weight (kg); Wt - Final Wet Weight $(\mathrm{kg})$; $\mathrm{t}$ - Time (7 days).

Daily Growth Rate of catfish seeds during a certain time is calculated using the following formula:

$$
L P H=\frac{W_{t}-W_{o}}{t} \times 100 \%
$$

Where: DWG - Daily Weight Growth (g/day); Wt - Average Weight of Final Rearing (g); Wo - Average Weight of Initial Rearing (g); T - Rearing time (days).

Furthermore, research data during the rearing period were tabulated using Microsoft Excel. Then, nitrate and phosphorus data were analyzed descriptively in the form of tables and figures. Meanwhile, the data in the form of growth parameters including the Specific Growth Rate of water hyacinth plants and the Daily Growth Rate (DGR) of catfish seeds were analyzed using ANOVA. If there is a real difference in the treatment, a further test of Duncan will be taken.

\section{RESULTS OF STUDY}

The results of observation during 42 days of rearing showed that the distribution of nitrate and phosphate in catfish seed rearing pools without administration of water hyacinth or control treatment $(A)$ enhanced accordingly to the increase in rearing period. On the contrary, nitrate distribution in the treatments using water hyacinth $(B, C$, and $D)$ decreased until the end of reading period while phosphate distribution increased in the second week of 
rearing then decreased in the third week of rearing until the end of rearing period (Figure 1 and 2).

The decrease in nitrate and phosphate distributions in the rearing ponds given by water hyacinth $(B, C, D)$ showed a pattern where the nitrate and phosphate decreased in line with the increasing frequency of water hyacinth replacement. The treatment of water hyacinth replacement with a frequency of every two weeks (D) provided the lowest nitrate and phosphate contents in the sixth week (the end of rearing period), which were respectively $0.79 \mathrm{mg} / \mathrm{L}$ and $0.06 \mathrm{mg} / \mathrm{L}$. Meanwhile, the treatment A (control) without administration of water hyacinth provided the highest nitrate and phosphate contents in the sixth week (the end of rearing period), which were respectively $1.01 \mathrm{mg} / \mathrm{L}$ and $0.13 \mathrm{mg} / \mathrm{L}$ (Figure 1 and 2).

The low content of nitrate and phosphate in the treatment $D$ (water hyacinth replacement with a frequency of every two weeks) was suspected as the levels of nitrate and phosphate in the culture media have been well utilized by water hyacinth as a source of nutrients to grow.

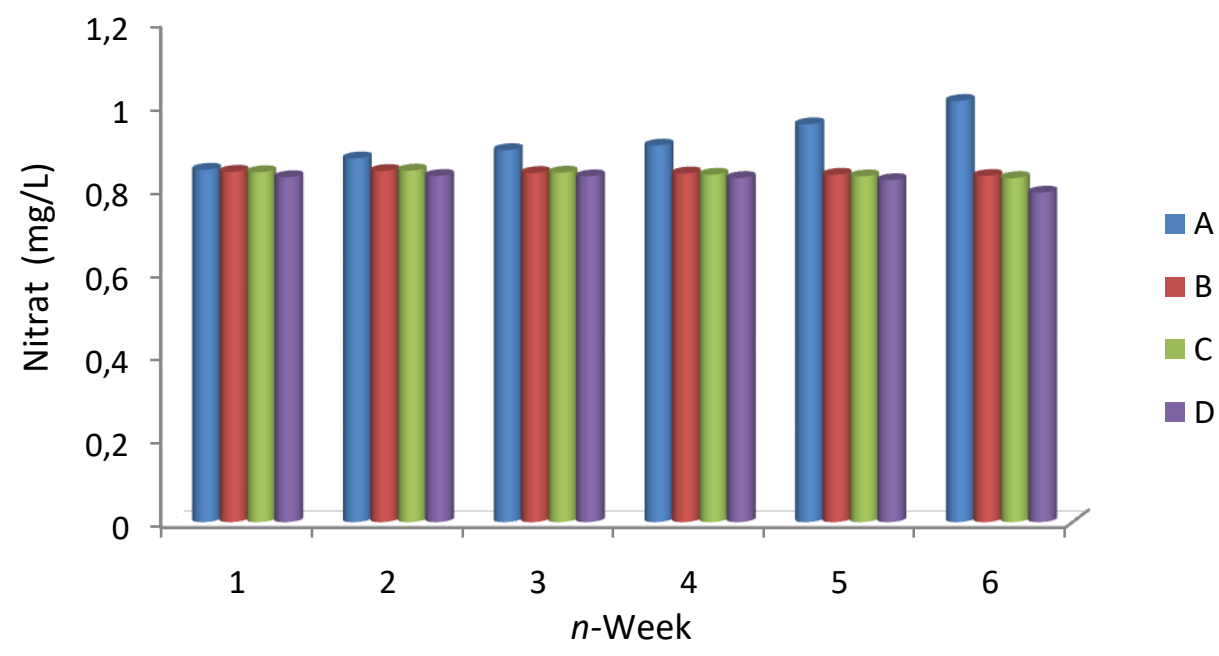

Figure 1 - Nitrate Concentration in Catfish Seed Rearing Pools with Water Hyacinth Fitoremediator for 42 days (Note: $A=$ control, $B=$ administration of water hyacinth without replacement, $C=$ water hyacinth replacement every 3 weeks, and $D=$ water hyacinth replacement every two weeks)

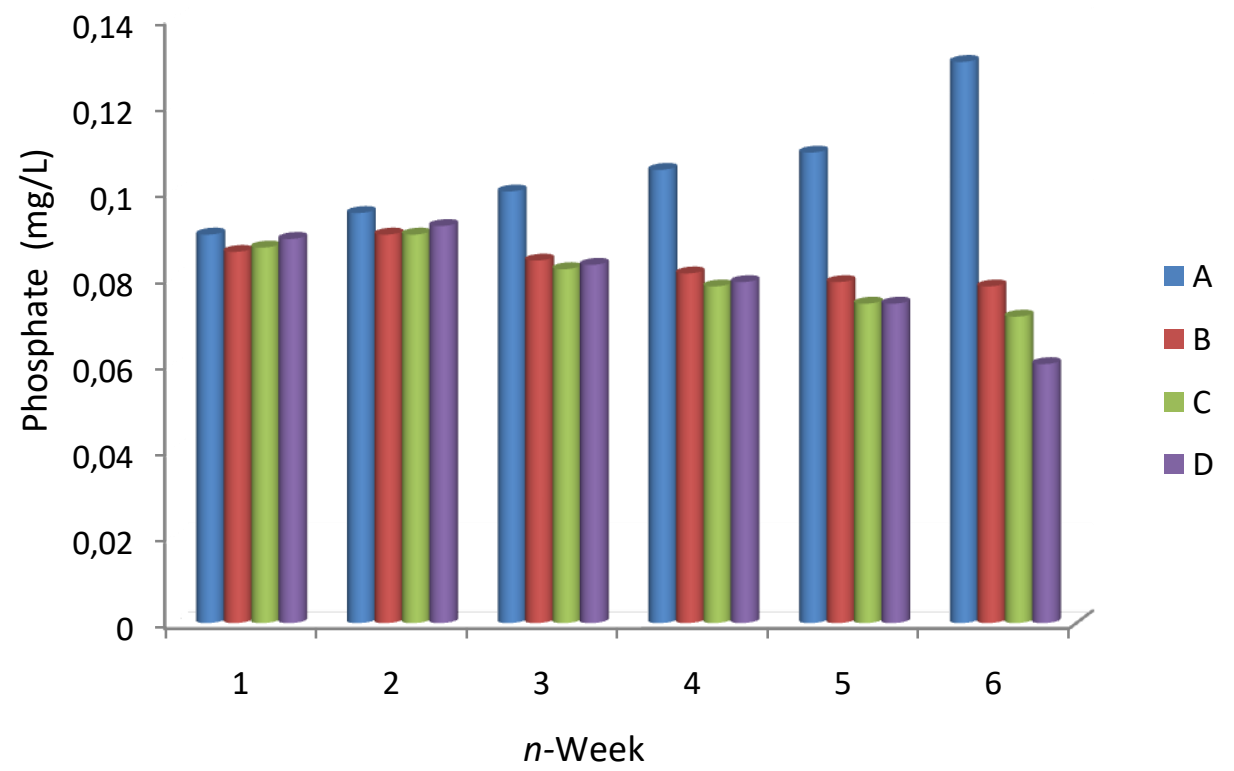

Figure 2 - Phosphate Concentration in Catfish Seed Rearing Pools with Water Hyacinth Fitoremediator for 42 days (Note: $A=$ control, $B=$ administration of water hyacinth without 
replacement, $\mathrm{C}=$ water hyacinth replacement every 3 weeks, and $\mathrm{D}=$ water hyacinth replacement every two weeks)

The calculation results of the Specific Growth Rate (SGR) of water hyacinth weight in catfish seed rearing for 42 days showed that the highest weight of water hyacinth was achieved at the frequency of water hyacinth replacement every three weeks (Treatment $C$ ) $(2.53 \% /$ day) while the lowest was in the Treatment B (administration of water hyacinth without replacement) (1.64\%/ day) (Figure 3).

The results of the ANOVA test showed that the treatments of various frequencies of water hyacinth replacement significantly affected the Specific Growth Rate $(P<0.05)$. Duncan's further test at $95 \%$ confidence interval showed that water hyacinth replacement with a frequency of every three weeks (Treatment $\mathrm{C}$ ) was not significantly different from that with a frequency of every two weeks (Treatment D). However, these two treatments were significantly different from the control treatment (Treatment A) and that without replacement (Treatment B).

A high Specific Growth Rate in the treatment of water hyacinth replacement with a frequency of every three weeks (C) and every two weeks (D) showed that the large ability of water hyacinth to grow in the treatments were allegedly due to the adequacy of nutrients, especially nitrates and phosphorus.

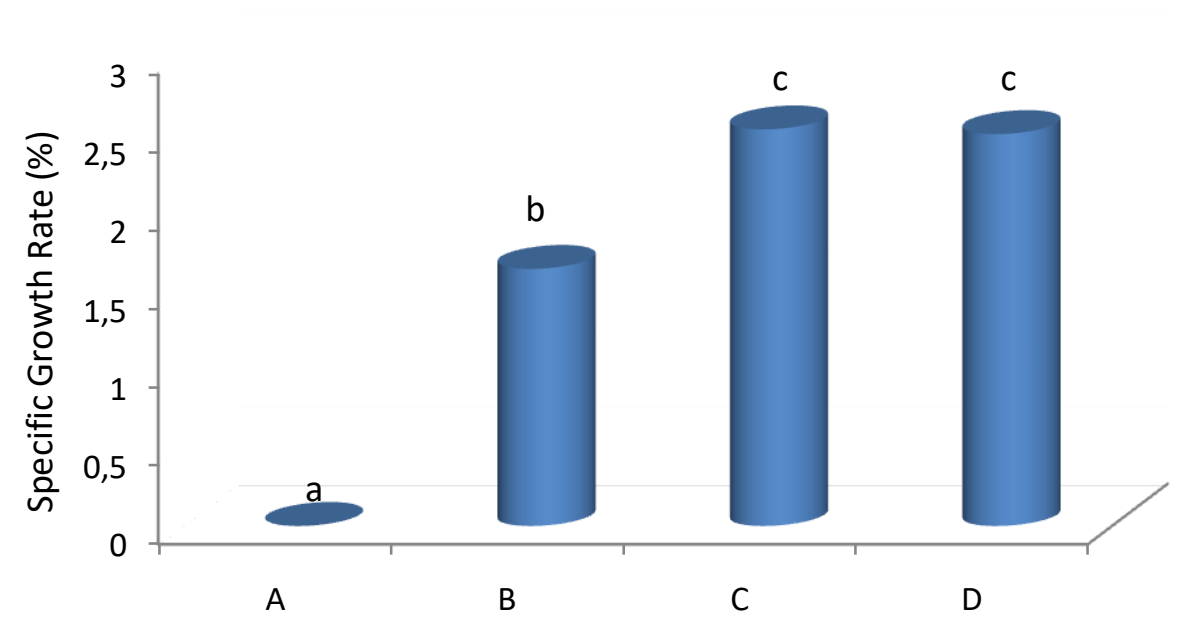

Figure 3 - Average Specific Growth Rate of Water Hyacinth as Phytormediator in Catfish Seed Rearing Ponds during 42 days (Note: $\mathrm{A}=$ control, $\mathrm{B}=$ administration of water hyacinth without replacement, $\mathrm{C}=$ water hyacinth replacement every 3 weeks, and $\mathrm{D}=$ water hyacinth replacement every two weeks)

The results of observation during 42 days of rearing showed that the Daily Growth Rate (DGR) of catfish seeds increased in line with the water hyacinth replacement treatments with various frequencies. It was obtained that water hyacinth replacement every two weeks (Treatment D) provided the highest catfish seed DGR of $5.46 \%$ / day while the control treatment or the treatment without the use of water hyacinth (Treatment A) had the lowest catfish seed DGR of $4.38 \%$ / day (Figure 4).

The results of the ANOVA test indicated that the treatments of various frequencies of water hyacinth significantly affected the Daily Growth Rate of catfish seeds $(P<0.05)$. Duncan's further test at $95 \%$ confidence interval showed that the water hyacinth replacement with a frequency of every three weeks (Treatment C) was not significantly different from the administration of water hyacinth without replacement (Treatment B). However, both treatments were significantly different from the control treatment (Treatment A) and the water hyacinth replacement with a frequency of every two weeks (Treatment D).

This condition illustrates that catfish seeds can grow and develop well in ponds given water hyacinth with a frequency of replacement every two weeks (Treatment D). It is suspected that replacing water hyacinth plants every two weeks can provide good water quality in the catfish seed rearing ponds. Good water quality can be a limiting factor in the 
culture media and increase the appetite of catfish, leading to an increase in its biomass as well.

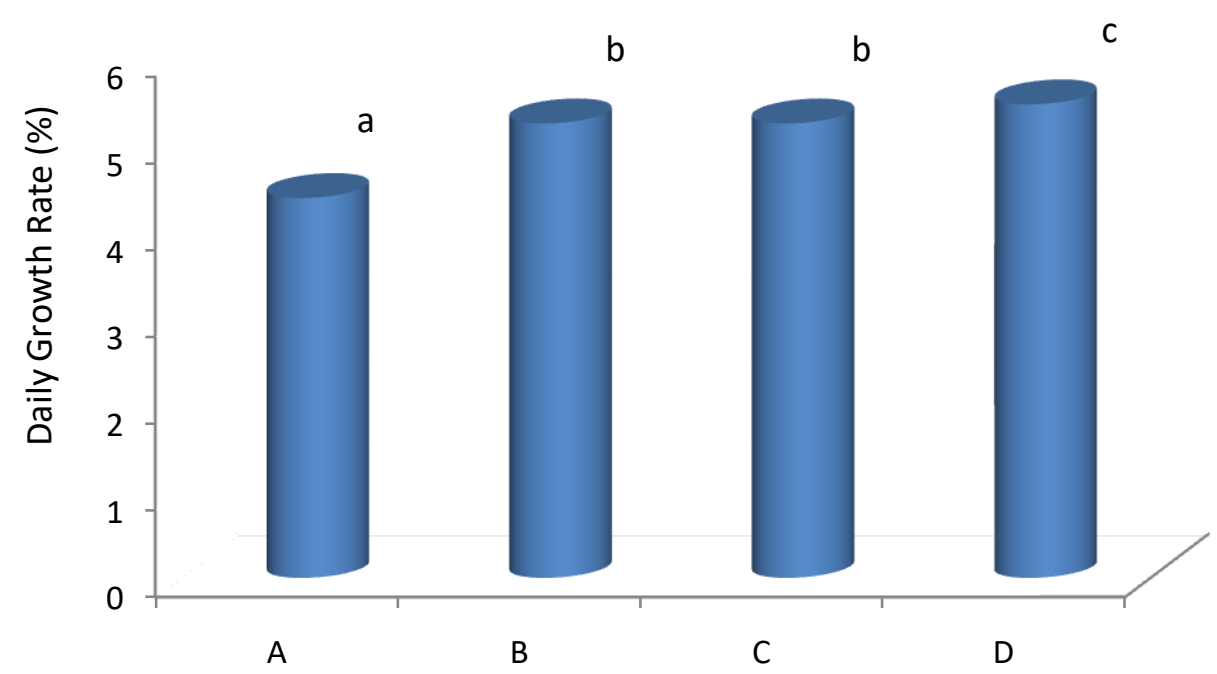

Figure 4 - Average Daily Growth Rate of Catfish Seed Rearing Ponds during 42 days (Note: $\mathrm{A}=$ control, $\mathrm{B}=$ administration of water hyacinth without replacement, $\mathrm{C}=$ water hyacinth replacement every 3 weeks, and $D=$ water hyacinth replacement every two weeks)

\section{DISCUSSION OF RESULTS}

One important aspect of the utilization of water hyacinth in fish culture media is to improve water quality. This research suggests that the improvement of water quality with the utilization of water hyacinth will be more optimal when it uses an appropriate frequency of replacement during the farming period. Overall, the results of this research indicate that the water hyacinth replacement with a frequency of every two weeks during 42 days gained the highest Daily Growth Rate (DGR) of catfish seeds, reaching $5.46 \%$ day (Figure 4). It is suspected that this condition was caused by differences in water quality. Good water quality can be a limiting factor in the culture media and increase the appetite of catfish. Water hyacinth replacement every two weeks causes an increase in water quality so that the feed given can be eaten, digested, and retained properly in the form of protein by catfish so that it can increase its Daily Growth Rate (Vass et al., 2015).

The improvement of water quality in the treatment of water hyacinth replacement every two weeks is higher than other treatments in this research, supported by the decrease in the contents of nitrates $\left(\mathrm{NO}_{3}\right)$ and phosphates $\left(\mathrm{PO}_{4}\right)$ in the culture media during 42 days of catfish seed rearing. At the end of the rearing period, the treatment of water hyacinth replacement with a frequency of every two weeks provided the lowest value of $0.79 \mathrm{mg} / \mathrm{L}$ for nitrate and $0.06 \mathrm{mg} / \mathrm{L}$ for phosphate (Figure 1 and 2). The concentration of nitrate and phosphate decreasing at the end of the rearing period is presumably due to being used by water hyacinth as a source of nutrients to grow. Wang et al. (2011) stated that $1 \mathrm{~kg}$ of water hyacinth can absorb $5.0 \mathrm{mg} / \mathrm{LP}-\mathrm{PO}$. This shows that water hyacinth has a significant ability to reduce the phosphate concentration in waters. Water hyacinth can absorb heavy metals, organic contaminants and nutrients from the water column (Villamagna and Murphy, 2010).

During this research, the nitrate concentration ranged from $0.79-1.01 \mathrm{mg} / \mathrm{L}$ while the phosphate concentration ranged from $0.06-0.13 \mathrm{mg} / \mathrm{L}$. According to Santhosh and Singh (2007), the nitrate concentration supporting for the freshwater fish farming ranges from 0.1 to $4.0 \mathrm{mg} / \mathrm{L}$. Meanwhile, Swan (2017) argued that the phosphate concentration in the culture media is 0.01 to $3.0 \mathrm{mg} / \mathrm{L}$. Thus, the nitrate content used during this research is considered to be in the normal range so that it is still safe for catfish life, but the phosphate content is in the range that is slightly higher than the normal range. Emmanuel et al. (2018) stated that phosphate is a limiting nutrient required for the growth of all aquatic plants. Phosphate is not 
toxic to humans or fish, except at very high concentrations that can cause digestive disorders in cultured fish. On another side, nitrate is generally stable under various environmental conditions and are very soluble in water. Compared to other inorganic nitrogen compounds, nitrate is relatively non-toxic. However, at very high concentrations, it can affect osmoregulation, oxygen transportation, eutrophication, and blooming algae (Stone and Thomforde, 2004).

The results of this research also showed that the nitrate concentration in the culture media decreased in all treatments with the use of water hyacinth. Moreover, the phosphate content increasing in the second week of rearing was presumably because water hyacinth had not been able to utilize phosphorus as phosphate directly from the rest of fish metabolism. However, during the third to sixth week of rearing, it appeared that water hyacinth had been able to utilize phosphorus as phosphate directly from the rest of fish metabolism because the phosphate content began to decrease in the third week until the end of the rearing period. On the other hand, in the treatment without administration of water hyacinth (Treatment $\mathrm{A} / \mathrm{C}$ Control Treatment), there was an increase in the nitrate and phosphate contents every week due to accumulation of fish metabolism and feed residues (Figure 1 and 2).

This condition further strengthens the assumption that the use of nitrogen as nitrate $\left(\mathrm{NO}_{3}\right)$ and phosphorus as phosphate $\left(\mathrm{PO}_{4}\right)$ by water hyacinth can reduce the pollution burden of fish culture media. Like other aquatic plants, water hyacinth can be used as a biological filter to change the form of inorganic nitrogen that is harmful to fish such as ammonia and nitrite into a harmless form, namely nitrates. Emmanuel et al. (2018) stated that nitrate $\left(\mathrm{NO}_{3}\right)$ is formed through the process of nitrification, that is the oxidation of $\mathrm{NO}_{2}$ to $\mathrm{NO}_{3}$ by the activity of aerobic bacteria. This mechanism occurs because water hyacinth becomes a substrate of the attachment of nitrification bacteria, namely Nitrosomonas and Nitrobacter. These bacteria utilize ammonia and nitrite to be used as food materials which will then form nitrates.

Water hyacinth can utilize nitrate and phosphate with nutrient uptake through its roots in the culture media. The absorbed nutrients will then be stored in their body tissues in the form of protein used to grow and survive in adverse environmental conditions. Furthermore, the concentration of nitrate and phosphate in water hyacinth tissues depends on the amount of nitrate and phosphate in the culture media (Okomoda et al., 2012). Vesely et al. (2011) revealed that nitrogen as nitrate $\left(\mathrm{NO}_{3}\right)$ and phosphorus as phosphate $\left(\mathrm{PO}_{4}\right)$ are the main inorganic nutrients needed for water hyacinth to grow. Other nutrients, both organic and inorganic, do not have as much effect as nitrates and phosphates.

The higher ability of water hyacinth to absorb nitrate and phosphate in the culture media will increase the growth value. Absorption ability of water hyacinth is increasingly enlarged by the frequency of water hyacinth replacement during the fish seed rearing period. This is supported by the measurement results of the Specific Growth Rate (SGR) of water hyacinth weight in this research, showing that the culture media of catfish seedlings with the treatment of water hyacinth replacement with a frequency of every three weeks was higher, which was $2.53 \%$ / day. However, these results were not significantly different from that with a frequency of every two weeks which showed a Specific Growth Rate of water hyacinth of $2.50 \% /$ day (Figure 3). Agen (2008) explained that the relatively high growth rate indicates the large growth ability of each plant during treatment. The higher average of Specific Growth Rate of water hyacinth in the treatment of replacement with a frequency of every three weeks is assumed to be caused by the growth of water hyacinth which has reached the doubling time (DT) before replacement. In contrast, the growth of water hyacinth has not reached the doubling time (DT) in the treatment of replacement with a frequency of every two weeks. Several studies have suggested that the value of doubling time (DT) of water hyacinth ranges between 3 - 64 days (Gutiérrez, 2001; Bianchini, 2015; Eid and Shaltout, 2016).

The treatment of water hyacinth replacement with a frequency of every two or three weeks during the catfish seed rearing can reduce the excessive increase in water hyacinth density to maximize the absorption of nutrients in the form of nitrate and phosphate by water hyacinth, affecting on the improvement of aquaculture water quality. High stocking density 
can reduce the growth space of water hyacinth so that nutrient needs become unbalanced. As shown by the results of this research, the treatment without the administration of water hyacinth (Control Treatment) showed a Specific Growth Rate of 1.64\% (Figure 3). Eid and Shaltout (2016) stated that the relatively low growth rate of water hyacinth when there is an increase in biomass is assumed to be due to their shades as a result of high density or intraspecific competition for light and space. The growth of water hyacinth is influenced by the availability of nutrients, plant density, light and season.

The reduction in the Specific Growth Rate of water hyacinth can also cause water hyacinth unable to tolerate the burden of catfish farming waste. The increased aquaculture waste will certainly increase the nutrients contained in the culture media to provide an opportunity for water hyacinth competitors, such as algae and heterotrophic bacteria, to grow and develop as well. Agren (2008) stated that slowing growth in plants, in general, is positively correlated to decreasing nutrient intake in planting media, which in this research refers to the media water used. It also shows the speed of plants in absorbing nutrients in waters.

\section{CONCLUSION}

Water hyacinth replacement with a frequency of every two weeks provides the lowest nitrate and phosphate contents at the end of the catfish seed rearing for 42 days, which is $0.79 \mathrm{mg} / \mathrm{L}$ for nitrate and $0.06 \mathrm{mg} / \mathrm{L}$ for phosphate, increasing the average Daily Growth Rate (DGR) of catfish seeds of $5.46 \% /$ day. Water hyacinth replacements with a frequency of every two weeks and every three weeks have the same effect on increasing the Specific Growth Rate (SGR) of water hyacinth, ie $2.50 \%$ / day and $2.53 \% /$ day respectively.

\section{REFERENCES}

1. Adeniran, E. 2011. The Efficiency Of Water Hyacinth (Eichornia crassipes) in The Treatment of Domestic Sewage in an African University. Annual Water Resources Conference. Lbuquerque. New Mexico.

2. Agren, G. I. 2008. Stoichiometry and Nutrition of Plant Growth in Natural Communities. Annual Review of Ecology, Evolution, and Systematics, 153-170.

3. Benli, A. C. K., Kokasal, G. and Ozkul, A. 2008. Sublethal Ammonia Exposure of Nile Tilapia Oreochromis niloticus L.: Effects on Gill, Liver and Kidney Histology. Chemosphere journal, 72(9): 1355-1358.

4. Bianchini, Jr, I., M. B. Cunha-santino, J. A. M. Milan, C. J. Rodrigues and J. H. P. Dias. 2015. Model Parameterization for The Growth of Three Submerged Aquatic Macrophytes . Journal of Aquatic Plant Management, 53: 64-73.

5. Boyd, C. E. 2015. Water Quality. New York (US). Springer Science, 2(2):133-136.

6. Brown, S. 1997. Estimating Biomass and Biomass Change of Tropical Forests: A Primer. FAO Forestry Paper 134. Food and Agriculture Organization of The United Nations. Rome.

7. Eid, E.M., and K. H. Shaltout. 2016. Population Dynamics of Eichhornia crassipes (C. Mart.) Solms in the Nile Delta, Egypt. Plant Species Biology: 1-12.

8. Emmanuel, A. E., Lillian, I. E and Samson, N. U. 2018. Effects of Water Hyacinth (Eichhornia crassipes) on the Physicochemical Properties of Fishpond Water and Growth of African catfish. African Journal of Agricultural Research, 13(2): 54-66.

9. Gutiérrez, E. L., E. F. Ruiz , E. G. Uribe and J. M. Martínez. 2001. Biomass and Productivity of Water Hyacinth and Their Application in Control Programs. Biological and Integrated control of water hyacinth, Eicchornia crassipes. ACIAR Proceeding 102. 109 119.

10. Ochekwu, E. B. and Madagwa, B. 2013. Phytoremediation Potentials of Water Hyacinth. Eichhornia Crassipes (Mart.) Solms in Crude Oil Polluted Water. Journal of Applied Sciences and Environmental Management, 17(4):503-507. 
11. Okomoda, V. T., Solomon, S. G., and Ataguba, G. A. 2012. Potential Uses of The Family Lemnaceae. Department of Fisheries and Aquaculture, University of Agriculture Makurdi. Journal of Agriculture and Veterinary Sciences. Nigeria. ISSN 2277-0062.

12. Remen, M., Imsland, A K , Steffanson, S. O., Jonassen, T. M. and Foss, A. 2008. Interactive Effects of Ammonia and Oxygen on Growth and Physiological Status of Juvenile Atlantic Cod Gadus morhua. Aquaculture, 274: 292-299.

13. Santhosh, B. and Singh, N. P. 2007. Guidelines for Water Quality Management for Fish Culture in Tripura, ICAR Research Complex for NEH Region, Tripura Center, Publication no. 29.

14. Skriptsova, A. V. and N. V. Miroshnikova. 2011. Laboratory Experiment To Determine The Potential Of Two Macroalgae from the Russian Far-East as Biofilters for Integrated Multi-Trophic Aquaculture (IMTA). Bioresour Technology, 102: 3149-3154.

15. Stone, N. M. and Thomforde, H. K. 2004. Understanding Your Fish Pond Water Analysis Report. Cooperative Extension Program, University of Arkansas at Pine Bluff Aquaculture / Fisheries.

16. Swann, L. 2017. A Fish Farmer's Guide to Understanding Water Quality. https://extension.purdue.edu/extmedia/AS/AS-503.html.

17. Ugya, A. Y. and Imam T. S. 2015. The Efficiency of Eicchornia crassipes in the Phytoremediation of Wastewater from Kaduna Refinery and Petrochemical Company. IOSR. Journal of Pharmaceutical and Biological Sciences, 10(1):76-80.

18. Veselý, T., Tlustoš, P. and Száková, J. 2011. The Use of Water Lettuce (Pistia stratiotes L.) for Rhizofiltration of a Highly Polluted Solution by Cadmium and Lead. International Journal of Phytoremediation, 13: 859-872.

19. Vass, K.K., Wangeneo, A., Samanta, S., Adhikari, S. and Muralidhar, M. 2015. Phosphorus Dynamics, Eutrophication and Fisheries in The Aquatic Ecosystems in India. Sustainable Phosphorus Management, Current Science, 108(7): 1306-1314.

20. Villamagna, A. M and B. R. Murphy. 2010. Ecological and Socio-Economic Impacts of Invasive Water Hyacinth (Eicchornia crassipes): A review. Freshwater Biology, 55: 282298.

21. Wang, H., H. Zhang, and G. Cai. 2011. An Application of Phytoremidiation to River Pollution Remidiation. Procedia Enviromental Sciences: 3rd International Conterence on Environmental Science and information Application Technology (ESIAT 2011) 10:19041907. 